\title{
Thomas Piketty's Book “Capital in the Twenty-First Century", Karl Marx and the Political Economy of the Internet
}

\section{Christian Fuchs}

\author{
University of Westminster, London, UK, christian.fuchs@uti.at, http://fuchs.uti.at
}

\begin{abstract}
Thomas Piketty's book Capital in the Twenty-First Century has resulted in a sustained political and academic debate about capitalism in the $21^{\text {st }}$ century. This article discusses the relevance of the book in the context of Karl Marx's works and the political economy of the Internet. It identifies 3 common reactions to Piketty's book: 1) dignification; 2) denigration of the work's integrity; 3 ) the denial of any parallel to Marx. I argue that all three reactions do not help the task of creating a New Left that is urgently needed in the situation of sustained capitalist crisis. Marxists will certainly view Piketty's analysis of capitalism and political suggestions critically. I argue that they should however not dismiss them, but like Marx and Engels aim to radicalise reform suggestions. In relation to the Internet, this paper discusses especially how insights from Piketty's book can inform the discussion of tax avoidance by transnational Internet companies such as Google, Facebook and Amazon. For establishing an alternative, non-commercial, non-capitalist Internet one can draw insights about institutional reforms and progressive capital taxation from Piketty that can be radicalised in order to ground radicalreformist Internet politics.
\end{abstract}

Keywords: Thomas Piketty, Capital in the Twenty-First Century, political economy of the Internet, progressive taxation, capitalism, alternative Internet, alternative social media, Karl Marx, Friedrich Engels, Marxism

"The daily struggle for reforms, for the amelioration of the condition of the workers within the framework of the existing social order, and for democratic institutions, offers to the social democracy the only means of engaging in the proletarian class war and working in the direction of the final goal-the conquest of political power and the suppression of wage labor. Between social reforms and revolution there exists for the social democracy an indissoluble tie. The struggle for reforms is its means; the social revolution, its aim" (Rosa Luxemburg 1899, 41).
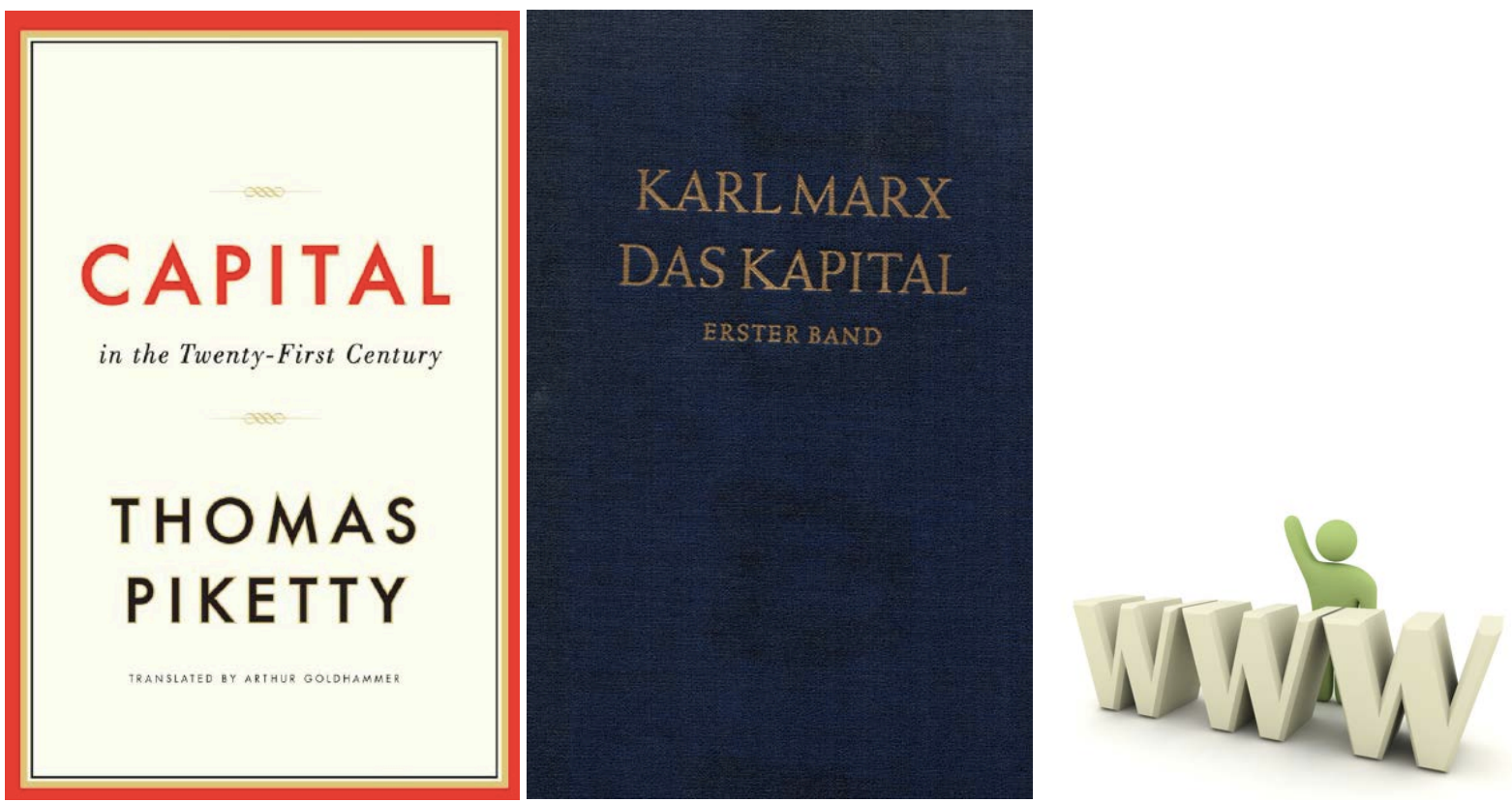

CC: Creative Commons License, 2014. 


\section{Three Kinds of Reactions to Thomas Plketty's Book}

In the reactions to and discussions of Thomas Piketty's (2014) monograph Capital in the Twenty-First Century, one can identify three ways how commentators position this book in relation to Karl Marx's works: 1) dignification, 2) denigration of the work's integrity, 3) denial of any parallel to Marx.

The first group of commentators dignifies Piketty's work and argues that he shows the topicality of Marx's works and has written the 21st century equivalent of Marx's (1867) Capital. James Pethoukis (2014) calls the book a version of "new Marxism" that shows that "now Marxism's fundamental truth" that "private capital accumulation inevitably leads to the concentration of wealth into ever-fewer hands [...] is reasserting itself with a vengeance". Daniel Shuchman (2014) wrote that Piketty "revives Marx for the 21st Century".

The New York Times published a review that argued that Piketty's book shows that "Karl Marx is back from the dead. [...] Piketty himself is a social democrat who abjures the Marxist label. But as his title suggests, he is out to rehabilitate and recast one of Marx's key ideas: that so-called 'free markets', by their nature, tend to enrich the owners of capital at the expense of people who own less of it" (Douthat 2014). A New York Times op-ed piece concluded: "Like Marx, he is fiercely critical of the economic and social inequalities that untrammeled capitalism produces - and, he concludes, will continue to worsen" (Erlanger 2014). Around the same time as the English version of Piketty's book came out, the New York Times published a feature that asked: "Was Marx right?" (The New York Times 2014). In it, Doug Henwood (editor of Left Business Observer), Michael R. Strain (American Enterprise Institute), Yves Smith (author of the blog Naked Capitalism), Tyler Cowen (professor of economics at George Mason University) and Brad DeLong (professor of economics at University of California, Berkeley) discussed whether Marx's works are topical or not.

Thomas Shenk (2014) argued in The Nation that Piketty shows the topicality of the critique of capitalism: "Though not a Marxist, Piketty is firmly of the left". Piketty's hostility to Marx(ism) would be unnecessary: "The hostility matches the temper among French intellectuals after their widespread turn against Marxism in the 1970s, but it is troubling to watch him snarling at prospective allies when the scale of the challenge facing advocates of equality is so daunting". There would be strong parallels between Marxism and Piketty's work: "Marxism is one kind of socialism, but history suggests a much richer set of possibilities, along with some grounds for hope. So does a work like Capital in the Twenty-First Century - a sign that another lost tradition, the postcapitalist visions in abeyance since the 1970s, could be poised for a return" (Shenk 2014).

Paul Krugman (2014b) wrote in a review: "It's not just the obvious allusion to Marx that makes this title so startling. By invoking capital right from the beginning, Piketty breaks ranks with most modern discussions of inequality, and hearkens back to an older tradition". He concluded: "Piketty has transformed our economic discourse; we'll never talk about wealth and inequality the same way we used to".

A second group of commentators holds that Piketty is just like Marx wrong and that his ideas are similarly dangerous. They try to denigrate the integrity of the book. The Economist wrote that Piketty is "bigger than Marx" (The Economist 2014) and that he just like Marx "glosses over the question of whether attempts to redistribute wealth will weaken growth". The Spectator concedes that "Pikkety has resurrected Marx from the ash-heap of history by proving that his central argument was true: the capitalist system is rigged to make the rich grow ever richer while ordinary classes sink into penury" (Mount 2014). It concludes however that Plketty's political vision is as repressive as the one Marx imagined: "this decaff Marxism would be just oppressive and intrusive as the old variety" (Mount 2014).

The most sophisticated attack has been launched by the Financial Times (Giles and Giugliano 2014). It is sophisticated because it does not challenge Piketty on political, but on academic grounds. The intention is obviously politically, namely to defend capitalist interests against the idea that the taxation of wealth and capital should be increased, but remains hidden. The Financial Times argues that it found "numerous mistakes in Prof Piketty's work: 
simple fat-finger errors of transcription; suboptimal averaging techniques: multiple explained adjustments to the numbers; data entries with no sourcing; unexplained use of different time periods; and inconsistent use of source data" (Giles and Giugliano 2014, 5). Correcting the data would show that "the European results do not show any tendency towards rising wealth inequality after 1970" and that the US data do not support "the view that the wealth share of the top 1 per cent has increased in the past few decades", although there "is some evidence of a rise in the top 10 per cent wealth share since 1970" (Giles and Giugliano 2014, 5).

The Financial Times' criticism concerns data for what Piketty terms "wealth inequality" in Britain (Piketty 2014, 344: figure 10.3) and the USA (Piketty 2014, 348: figure 10.5). Piketty uses the term wealth interchangeably with the term capital (Piketty 2014, 47) and includes in it "everything owned by the residents and government of a given country at a given point in time, provided that it can be traded on some market" (Piketty 2014, 48). Capital therefore comprises for him "nonfinancial assets (land, dwellings, commercial inventory, other buildings, machinery, infrastructure, patents, and other directly owned professional assets) and financial assets (bank accounts, mutual funds, bonds, stocks, financial investments of all kinds, insurance policies, pension funds, etc), less the total amount of financial liabilities (debt)" (Piketty 2014, 48).

Notwithstanding the question if capital is a stock or a social relation, it becomes evident that the two figures the Financial Times questions are about the distribution of owned assets within the property-owning class. It does not concern the question how the surplus-product is distributed between capital and labour because labour power is excluded from these specific statistics. Chapter 10 of Piketty's book, in which the two figures that the Financial Times criticises, is focused on the "inequality of capital ownership", so its title. It is about the question how capital concentration has developed. So we are talking about capital concentration and not income inequality or the relationship between capital and labour. No matter if capital is more or less concentrated, capital as a totality, the collective capitalist, exploits and excludes labour that creates capital from ownership. Labour is not-capital: it creates, but does not own capital. Marx stresses that labour is "not-value", "not-capital", "not-raw-material", "notinstrument of labour", "not-raw-product" (Marx 1857/1858, 295): it is "absolute poverty", which means an "exclusion from objective wealth" (Marx 1857/1858, 296) and at the same time the constitution of labour as the "living source of value", the "general possibility" of wealth (Marx 1857/1858, 296).

Piketty discusses the question of the capital/labour relationship in chapter 6 and shows sustained inequality deriving from capital's exploitation of labour. The Financial Times concludes on the front page of its weekend edition published on May 24/25, 2014, in one of the headlines that "Piketty did his sums wrong in bestseller that tapped into the inequality zeitgeist". It wants to communicate that inequality is no contemporary problem and that Piketty is all wrong. Piketty's concept of wealth is somewhat misleading because it does not focus on the capital-labour relationship and Marx's insights that labour creates capital and that work is the source of wealth. He nonetheless provides important data about the capital-labour relationship that is not refuted by the Financial Times. Paul Krugman (2014a) commented that the Financial Times' claim of "stable wealth concentration in the United States is at odds with many sources of evidence". Thomas Piketty: "Where the Financial Times is being dishonest is to suggest that this changes things in the conclusions I make, when in fact it changes nothing. More recent studies only support my conclusions, by using different sources" (Rankin 2014a).

A third group of commentators holds that Piketty's analysis is not Marxist at all and that Marx and Marxist theory provide superior analyses. They deny parallels to Marx. Piketty himself positions his work partly against Marx, especially when he associates Marx's ideas of the abolishment of private property and the creation of the collective ownership of the means of production with "the Soviet experiment", "totalitarian experiments" (Piketty 2014, 531) and the "human disasters caused by Soviet-style centralized planning" (532). "I belong to a generation that came of age listening to news of the collapse of the Communist dictatorships and never felt the slightest affection or nostalgia for those regimes or for the Soviet Union. I was vaccinated for life against the conventional but lazy rhetoric of anticapitalism, some of which 
simply ignored the historic failure of Communism and much of which turned its back on the intellectual means necessary to push beyond it. I have no interest in denouncing inequality or capitalism per se - especially since social inequalities are not in themselves a problem as long as they are justified" (Piketty 2014, 31).

One cannot blame Marx for Stalin. Stalin was just four years old when Marx died in 1883, which did not allow Marx to account for and comment on what Stalin did as Soviet dictator. Marx furthermore stressed that communism is the "struggle for democracy" (Marx and Engels 1848b, 481). Marx would have disapproved of Stalin's presentation of Soviet state capitalism as socialist society that is on its pathway towards communism simply because the workers were not in control of production and were dominated by bureaucracy.

Piketty's scepticism of Marx explains why Marxist authors tend to be sceptical of Piketty. Andrew Kliman (2014) commented that "the disproportionate concern over inequality [in Piketty's book] can divert attention from major economic problems like the economy's failure to rebound from the Great Recession, and what to do about that". David Harvey (2014) criticised that Piketty's book "does not tell us why the crash of 2008 occurred" and that, although his empirical data would be valuable and his suggestions for progressive taxation of wealth, inheritance and capital thoughtful, he would not provide a theory of capitalism in the twentyfirst century so "that we still need Marx or his modern-day equivalent".

Harvey (2014) also questions Piketty's definition of capital as too broad: "Money, land, real estate and plant and equipment that are not being used productively are not capital". Hans Despain (2014) stresses: "Piketty's definition of capital is highly problematic. Piketty defines capital as all physical equipment, land, housing, money, financial assets, and other valuables. To his credit he excludes so-called 'human capital'. To count and aggregate these heterogeneous capitals Piketty estimates market prices. Thus, for Piketty capital is strictly monetary and financial. [...] Marx attempted a far more philosophical definition of capital as value. Marx's notion of value captures the philosophical, moral, sociological, psychological, political economic, and monetary and financial aspects of capital. In this definition, capital is a social relationship that establishes the relations of production. This places Marx's argument purposefully in the sphere of production. Piketty's definition leaves his argument in the sphere of distribution. The book is not directly about capital, at least not capital in the Marxian sense. Rather the book concerns the accumulation of wealth and financial assets". James Galbraith (2014) makes a similar point from a neo-Keynesian perspective: He argues that Piketty "conflates physical capital equipment with all forms of money-valued wealth, including land and housing, whether that wealth is in productive use or not". Galbraith concludes that the "book is not the accomplished work of high theory that its title, length, and reception (so far) suggest".

For Marx (1885, chapter 8), resources such as equipment, land and houses become capital if they are employed as means of production for the creation of commodities in the capital accumulation process. He speaks in this context of fixed constant capital that remains in the production process for a longer time. If a person owns a house and a garden for private living, then these assets are for Marx not capital. If s/he rents it out, then s/he earns rent that is paid out of wages or profits. If the renter is a company that turns the garden and the house into an office or a factory for the production of commodities, then both the land and the house become means of production and fixed constant capital. Capital implies social relations between capital and labour, competing capitalists, capitalists and banks, rentiers and renters. So if land becomes capital this implies that labour standing in class relations uses it as a means of production in order to produce capital and that the land must have either been bought or rented by a company, which implies a sales relationship.

Marx pinpoints the difference between capital conceived as thing and social relation: "But capital is not a thing, it is a definite social relation of production pertaining to a particular historical social formation, which simply takes the form of a thing and gives this thing a specific social character. Capital is not the sum of the material and produced means of production. Capital is the means of production as transformed into capital, these being no more capital in themselves than gold or silver are money. It is the means of production monopolized by a particular section of society, the products and conditions of activity of labour-power, which 
are rendered autonomous vis-à-vis this living labour-power and are personified in capital through this antithesis" (Marx 1894, 953).

Paul Mason rejects the comparison of Piketty to Marx: "Is Piketty the new Karl Marx? Anybody who has read the latter will know he is not. Marx's critique of capitalism was not about distribution but production: for Marx it was not rising inequality but a breakdown in the profit mechanism that drove the system towards its end. Where Marx saw social relationships between labour and managers, factory owners and the landed aristocracy - Piketty sees only social categories: wealth and income. Marxist economics lives in a world where the inner tendencies of capitalism are belied by its surface experience. Piketty's world is of concrete historical data only. So the charges of soft Marxism are completely misplaced" (Mason 2014).

Some Marxist scholars also question Piketty's political conclusions. Harvey (2014) says his "remedies for the inequalities are naïve if not utopian". Despain (2014) argues even that they are reactionary: "Piketty's policy recommendations are impressively anemic and aimed at perpetuating exploitation of the economically vulnerable populations. In the end Piketty wants to take the 'hyper' out of hyperexploitation and reestablish good old-fashion exploitation with higher minimum wages, taxes on capital, progressive income tax, and limits on inheritance. [...] Piketty's policy recommendations can be described as hyperliberalism. [...] Nonetheless, there is no acknowledgement that democracy should be extended into the totalitarian workplaces of capitalism. He theorizes an entire chapter on the 'utopian' notion of a progressive 'global' tax capital as at least a reference point for more practical policy (515-39). Why not offer a gesture toward democratizing the workplace for income distribution? Why not acknowledge the self-directed worker enterprises, such as the Mondragon Corporation of Spain, have successfully reduced inequality between employees?". Sean Collins concludes that Piketty's book is a "navel-gazing distraction with zero progressive content" (Collins 2014).

Dignification, denigration and denial do not seem to be adequate responses to Piketty's work to me. Whereas the first position is rather purely affirmative and celebratory, the latter two tend to be purely dismissive. My own assessment is in contrast that Piketty's book is neither completely different from Marx's approach nor unrelated.

\section{Piketty and Marx}

Piketty's main assumption that he tries to show empirically is that inequality emerges in capitalism when "the rate of return on capital exceeds the rate of growth of output and income" (Piketty 2014, 1). Piketty $(2014,9)$ argues that Marx predicted "an apocalyptic end to capitalism: either the rate of return on capital would steadily diminish (thereby killing the engine of accumulation and leading to violent conflict among capitalists), or capital's share of national income would increase indefinitely (which sooner or later would unite the workers in revolt)". He here combines a specific interpretation of Marx's theorem of the tendency of the profit rate to fall with the assumption that he assumed that capitalism implies absolute immiseration of workers. Piketty $(2014,9)$. argues that by the end of the $19^{\text {th }}$ century wages began to increase and that increasing productivity and technological progress can act against capital concentration. He however overlooks that for Marx the first tendency was not a deterministic law because he identified countervailing tendencies (Marx 1894, chapter 14) and that for Marx the wealth gap between capital and labour need not necessarily become ever larger in absolute terms. Marx did not predict the breakdown of capitalism. It is simply not true that Marx's "principle of infinite accumulation" implies apocalypse because he "implicitly relies on a strict assumption of zero productivity growth over the long run" (Piketty 2014, 27).

In chapter 25 of Capital Volume 1, Marx (1867) describes what he terms the general law of capitalist accumulation. "But all methods for the production of surplus-value are at the same time methods of accumulation, and every extension of accumulation becomes, conversely, a means for the development of those methods. It follows therefore that in proportion as capital accumulates, the situation of the worker, be his payment high or low, must grow worse" (Marx 1867, 799). 
This key passage can easily be misread as capital accumulation implying absolute immiseration. Marx stresses however that with capital accumulation the worker's situation "must grow worse" no matter if his/her payment is "high or low". This formulation implies that accumulation does not necessarily bring about an absolute lowering of wages or the wage-sum, but that even if capitalists at point $t+1$ pay higher wages than at point $t$ because profits have increased, the workers do not own the monetary profits and commodities they produced. If a company or economic sector is not struck by crisis, it successfully increases its capital. This constant increase and re-investment for further increasing capital is only possible if the workers do not own the monetary profit. As capital grows, the workers situation grows worse because the absolute amount of capital that they do not own increases.

Piketty measures inequality between capital and labour in relative terms. He shows that capitalism's history has been a history of capitalists trying to increase their profits at the expense of labour. Marx's general law of capitalist accumulation describes that all capital accumulation dispossesses workers of surplus and profits and that therefore inequality of ownership is inherently built into capitalism. For Marx, there can be no just form of capitalism. Marx did however not assume, as incorrectly stated by Piketty, that inequality results in a necessary breakdown of capitalism. If capitalism breaks down is for Marx a question of social action, i.e. of class struggles and revolution.

Crises and capitalist contradictions condition the possibilities for working class struggles. The overthrow of the system can however only be an act of agency. This becomes evident when Marx for example stresses that "the greatest productive power is the revolutionary class itself" (Marx 1846/47, 181), that all social life is essentially practical and that the coincidence of the changing of circumstances and of human activity or self-changing can be conceived and rationally understood only as revolutionary practice (Marx 1845, 371f). Decisive is the "historical self-initiative ["self" is missing in the English translation although it can be found in the German original, CF]" (Marx and Engels 1848b, 490) of the dominated and that history is "the history of class struggles" (ibid., 462).

In the famous passage in Capital Volume 1, in which Marx describes revolution, he does not describe it as a systemic necessity, but as a structural development that conditions an active process of the proletariat: "The monopoly of capital becomes a fetter upon the mode of production which has flourished alongside and under it. The centralization of the means of production and the socialization of labour reach a point at which they become incompatible with their capitalist integument. This integument is burst asunder. The knell of capitalist private property sounds. The expropriators are expropriated".

Marx here does not say the capitalism "bursts asunder", but that it "is burst asunder". He does not say that the capitalist system expropriates capitalists via its own breakdown, but that they "are expropriated" by the proletarians. This implies revolutionary agency on behalf of the proletariat. Marx imagines that this situation happens and describes it in a lively manner. He does not assume that it occurs with necessity. Piketty underestimates the dialectic of structure and agency, capitalist contradictions and class struggles, in Marx's works.

Piketty however also concedes that Marx correctly identified accumulation as being dialectically connected to the workers' expropriation and resulting inequalities when saying that relatively rising inequality as in contemporary capitalism "directly reflects the Marxian logic" (Piketty 2014, 11). So Piketty does not dismiss Marx, but misinterprets him, which is not a surprise because when being asked about Karl Marx, Piketty said: "I never managed really to read it" (Chotiner 2014).

Piketty (2014) identifies as sources of contemporary inequality high remunerations of managers $(24,314 \mathrm{f})$, the high growth of profits, dividends, interests and rents (25), long-term slow growth coupled with high savings (173), the privatisation of public assets (173), a skills gap (304-307, 315), low taxation of profits and income (355), and inherited wealth (424-429). Piketty's main variables for analysing the consequences and realities of inequality are the capital/income share (chapter 5), the capital-labour split (chapter 6), the distribution of labour income (chapter 9), and the concentration and distribution of capital and wealth (chapter 10). He thereby shows the historical realities of inequality between capital and labour as well as capital concentration. The typical development of the capital-labour split, labour incomes and 
capital concentration takes on U-shaped curves with especially high levels of inequalities in the $19^{\text {th }}$ and early $20^{\text {th }}$ centuries and since 1970 s or 1980 s.

Piketty discusses Marx's law of the tendency of the profit rate to fall: "Marxist analysis emphasizes the falling rate of profit - a historical prediction that turned out to be quite wrong" (Piketty 2014,52 ). The profit rate would in the long run be relatively stable but would have decreased from levels of $4-5 \%$ in the $18^{\text {th }}$ and $19^{\text {th }}$ centuries to $3-4 \%$ today (Piketty 2014 , 206). Piketty argues that Marx's law of the tendency of the profit rate to fall means that "the bourgeoisie digs its own grave" (227) because Marx would have assumed that he average profit rate ever more diminishes. Marx would have overlooked the growth of productivity and population (228) and the diffusion of knowledge (234).

Here again Piketty's reading of Marx is not thorough enough. Marx spoke of a "tendency" of the profit rate to fall and not an automatism. This tendency would derive from the increasing role of constant capital, especially technology, in production so that the organic composition of capital $c / v$ (the relationship of constant and variable capital, i.e. the monetary value of means of production and labour power) increases. Marx (1894, chapter 14) furthermore identified countervailing tendencies, such as the lowering of wages, the usage of the methods of absolute and relative surplus value production, the cheapening of constant capital, foreign trade and the sale of commodities above their value, high exploitation rates of labour in colonies, the devaluation of fixed constant capital, increasing speed of the turnover of capital, and violent devaluation of capital by war or crises. Ernest Mandel commented in his introduction to Capital, Volume 3: "To be sure, Marx explicitly speaks about a tendency, not an uninterrupted linear development. He stresses that there are powerful countervailing forces at work under capitalism. The most important countervailing force is the possibility for the capitalist system to increase the rate of surplus-value" (in: Marx 1894, 31). Marx (1894, 339342) stresses that methods of absolute and relative surplus value production increase the rate of exploitation and so the "law [of the tendency of the profit rate to fall] operates more as a tendency, i.e. as a law whose absolute realization is held up, delayed and weakened" (Marx 1894, 341).

Within Marxist theory, there have been quite fierce battles about the validity or faultiness of Marx's tendency of the profit rate to fall (see: Ebermann, Heinrich, Kurz and Vogl 2011; Heinrich 2013a, 2013b; Kliman, Freeman, Potts, Gusev and Cooney 2013, Carchedi and Roberts 2013, Mage 2013, Moseley 2013). Scholars involved in these academic battles will of course always reject and deny the claim that these debates tend to be sectarian and dogmatic because they always perceive the others as sectarians and never themselves. The problem often is not just the aggressive language used in such debates, but also that those involved tend to lose sight of the forest for the trees. They tend to get so invested in stressing differences and that other Marxists are wrong, interpret Marx falsely etc and that they have the only valid interpretation of Marx that they lose the sense for a big commonality, namely the interest in Marx's theory and the political opposition to capitalism. The lose sight of how important it is to together tackle the enemy in theory and politics. The in the course of the ongoing capitalist crisis growing camp of conservatives, right-wingers and fascists can definitely be thankful for such inward-directed theoretical and political wars.

All of this is dogmatism, orthodoxy, and sectarianism. But of course those involved will never admit to it. Hopefully the time will come that they at least change their strategy. If so, then it will most likely be done without them admitting to their own sectarianism. David Harvey is arguably the most well known Marxist theorist today. But of course the sectarians will deny this fact, will stress how wrong Harvey is, that they are right, have the correct interpretation of Harvey, etc. Such claims are however nothing more than uninteresting and a waste of time. When Harvey says that we still need Marx's "modern-day equivalent" instead of Piketty, then psychoanalytically he may project himself into this position. But may it not be that besides all the repression, institutional and structural discrimination that Marxist have to face in capitalist society, which much limits the attention and visibility they get, one factor that contributes to the fact that Marxists don't have a figure with the same media and public presence as Piketty may be that they invest too much time in internal battles instead of in outward-oriented struggles? 
Debates about Marx's law of the tendency of the profit rate to fall often centre around the question if Marx's crisis theory is more a structural or an agency-focused theory that is determined either by structural antagonisms or class struggles. The basic question is if the profit rate varies because of a structural historical increase of the organic composition of capital or because of the outcomes of struggles between capital labour that are reflected in the relationship of the profit and wage share.

The rate of profit (ROP) is the relationship of profit and investment or of the monetary expression of surplus-value and the value of the means of production (constant and variable capital).

$R O P=\frac{s}{c+v}$

If we divide the numerator and the denominator by $\mathrm{v}$, then we get:

$R O P=\frac{\frac{s}{v}}{\frac{c}{v}+1}$

This formula shows that the rate of profit depends a) on the rate of surplus-value that Marx also calls the rate of exploitation because it describes the relationship of unpaid and paid labour and b) the organic composition of capital that represents the relationship of dead and living labour, constant and variable capital, the value of machinery/resources and labour power. The rate of profit is directly proportional to the rate of surplus-value and indirectly proportional to the organic composition of capital.

Capitalists have to constantly strive to increase productivity in order to survive and produce more commodities in less time. So they strive to invest in more efficient production technologies and to speed up production and circulation. The rise of computing in production or what some term the information economy and information society is grounded in the technification of production and the development of the productive forces. As a result, science and knowledge in production and society have historically increased their importance. Technification as means for raising productivity is likely to bring about an increase of the organic composition of capital because more money tends to be spent on technology. It however also tends to increase the rate of surplus-value because technology in production is according to Marx (1867) a means of relative surplus-value production resulting in the production of more value in less or the same time. So the same amount of labour measured in hours suddenly produces more surplus-value than before. It is clear that if the rate of surplus-value remains constant, while the organic composition rises, the rate of profit decreases.

There is a contradiction between the rate of surplus-value that is directly proportional to the rate of profit and the organic composition of capital that is indirectly proportional to it. In a situation of technological innovation, in which new technologies are adopted by many companies and so widely diffuse into the capitalist economy, additional constant capital investments tend to be made. If technologies are not cheapened, then this will result in an increase of the organic composition. The question is how capitalists will react to this downward pressure on their profits. It is likely that many of them attempt to mobilise countervailing tendencies, such as laying off labour, reducing wages, outsourcing labour, making employees work more for the same or lower wages, etc. They aim to always further increase the rate of surplus-value by various methods of absolute and relative surplus-value production. Technification is a method of relative surplus-value production itself, so raising the organic composition can increase the rate of surplus-value. There is however no guarantee that this increase is larger than the increase of the organic composition and so capitalists will tend to try to continuously reduce wage costs in order to increase profitability.

Methods of absolute and relative surplus-value production are however, as Marx knew, contested. Workers' struggles are not an automatism, but always a possibility. Workers have the capacity to resist capitalists' attacks so that the rate of surplus-value is also shaped by 
the outcomes of class struggles. If workers' struggles are successful, the rate and therefore their exploitation tend to decrease. If they are not successful, capitalists triumph and increase the rate of exploitation. The increase of the organic composition as structural tendency of capital stands in a contradiction to class struggles. The outcomes of this contradiction cannot be predicted in advance, but depend on historical circumstances. If the organic composition increases and there are no or unsuccessful workers' struggles so that the wage sum decreases, then the rate of profit can increase. If however workers' struggles are successful and they resist lay-offs and achieve wage-increases, the profit rate is more likely to fall.

Marx argues that capitalism is a vampire-like machine that sucks out labour: "Capital is dead labour which, vampire-like, lives only by sucking living labour, and lives the more, the more labour it sucks" (Marx 1867, 342). Capitalism's very structure compels capitalists to try to exploit labour as much as possible in order to survive in the competitive race and to increase its profits. So there is a necessary class struggle from above in capitalism. If capital could, then it would reduce wages as far as possible towards zero in order to increase profits. If it had unlimited supply of, access to and coercive power over labour power, it would pay no wages at all and make workers toil for 24 hours a day in order to maximise profits. Capital is inherently fascist potentials. The question is if labour reacts to exploitation with struggles or is blinded and kept still by ideologies. Two means of capitalist class struggle for increasing exploitation are absolute and relative surplus-value production.

One can sometimes hear that the early Marx was more a humanist focusing on agency and the old Marxist a functionalist describing capital's structural contradictions. This assumption is however odd, just like the claim that there has been an epistemological break in the work of the young "esoteric" and the old "scientific" Marx. Marx in contrast describes in detail in Capital Volume 1 how workers struggled against and resisted absolute and relative surplus-value production. Capital's attempts to ever more prolong the working day, called counter-struggles of the proletariat. In "the history of capitalist production, the establishment of a norm for the working day presents itself as a struggle over the limits of that day, a struggle between collective capital, i.e. the class of capitalists, and collective labour, i.e. the working class" (Marx 1867, 344). "The establishment of a normal working day is [...] the product of a protracted and more or less concealed civil war between the capitalist class and the working class" (Marx 1867, 412f).

Technification as method of relative surplus-production just like the intensification of control, surveillance and the speed of production as comparable methods can call forth resistance of workers who are concerned about lay-offs, quality of work and life, and absolute or relative decreases of wages. "In general, relative surplus-value is produced by raising the productivity of the worker, and thereby enabling him to produce more in a given time with the same expenditure of labour" (Marx 1867, 534). Workers' struggles against relative surplusvalue production often contest the implications of the introduction of new technologies, such as lay-offs, an increased pace of work, the standardisation of work routines, deskilling, etc. "The struggle between the capitalist and the wage-labourer starts with the existence of the capital-relation itself. It rages throughout the period of manufacture. But only since the introduction of machinery has the worker fought against the instrument of labour itself, capital's material mode of existence. He is in revolt against this particular form of the means of production because it is the material foundation of the capitalist mode of production" (Marx 1867, 553f).

Some Marxists tend to argue that a revolutionary approach is only possible based on the the assumption that capitalist development is governed by one structural law that with necessity brings about crises and over time brings us close to the end of capitalism. Along comes often the argument that class struggle explanations of crises are underconsumptionist, distributionist and reformist, that they ignore the structural contradictions of capitalism, aim at making capitalism work better and assume that an equal distribution is possible within capitalism. Underconsumption can also be framed as overproduction. Class conflict and struggle over the distribution of surplus-value is a structural contradiction of capitalism itself. It cannot be overcome as long as capitalism exists. Capitalists again and again try to drive down wage costs in order to increase profits and thereby foster capitalist contradictions. If 
this class struggle from above is however structural, then no fair distribution of capital and wealth is possible within capitalism. Capitalists have to exploit workers and therefore create inequality understood as an antagonism between those who own the means of production and the poverty (that Marx understood in the Grundrisse as non-ownership) of the working class as a structural feature of capitalism.

It is not feasible to assume that there is only one antagonism of capitalism and that it is always the same contradiction that calls forth crises because capitalism is a complex, dynamic system (Fuchs 2002, Fuchs 2004). Deterministic and one-dimensional crisis theories fail to account for this nature of capitalism. It is rather more feasible to assume that capitalism has a set of inherent antagonism revolving around the dialectic of capital and labour and that a specific crisis is a manifestation of an interaction of several antagonisms (Fuchs 2002, Fuchs 2004, Fuchs and Sandoval 2014b). For Marx, capitalism's antagonisms include the ones between classes; producers and the means of production, necessary and surplus labour, use-value and exchange-value, productive forces and the relations of production, single production and social need; socialised production and capitalistic, private appropriation; the fictitious value of financial capital and the actual profits that capital achieves on the commodity markets, etc (ibid.). The task is then to analyse how capitalism's antagonisms interact and develop historically and in specific crisis situations.

Back to Piketty's book, we can based on the preceding discussion argue that he fails to see the complexity and manifoldness of Marx's crisis theory and capitalism's dialectic of structure and agency. Marx is not an apocalyptic rider, but a communist soldier engaged in waging war against capitalism. One of Piketty's basic arguments is that historically there have been "numerous shocks to capital", but that capital has managed to again and again grow in the long-term by increasing inequality. Marx's insight was that this inequality is a structural feature of class society that in capitalism takes on the form of private property ownership of capital and the exploitation of labour. Piketty shows the ups and downs of capitalist development, which not just shows capital's capacity to restore growth by increasing and extending the exploitation of labour, but also its inherent crisis-proneness. Marx showed that there are inherent crisis-tendencies of capital that result again and again in crisis and that the growth, stagnation and decline of capital are conditioned by structural antagonisms and class struggles.

Marx saw the concentration of capital as an inherent tendency of capitalism that arises from the drive that capitalists have to ever more increase productivity. The progress of the use of technology and the rise of productivity tend to be distributed asymmetrically so that some companies can produce cheaper than others. Competition reverts in capitalism into the tendency of capital concentration. "This expropriation is accomplished through the action of the immanent laws of capitalist production itself, through the centralization of capitals. One capitalist always strikes down many others. Hand in hand with this centralization, or this expropriation of many capitalists by a few, other developments take place on an ever-increasing scale, such as the growth of the co-operative form of the labour process, the conscious technical application of science, the planned exploitation of the soil, the transformation of the means of labour into forms in which they can only be used in common, the economising of all means of production by their use as the means of production of combined, socialized labour, the entanglement of a 11 peoples in the net of the world market, and, with this, the growth of the international character of the capitalist regime" (Marx 1867, 929). Marx explained the tendency that Piketty (2014, chapter 10 ) calls the "inequality of capital ownership". Marx spoke of the concentration and centralisation of capital.

The concern about capitalism's inequalities unites Piketty and Marx more than Piketty and the contemporary Marxist, liberal and conservative commentariat tend to realise. At the same time their perspectives also diverge because Piketty takes a predominantly empirical and Marx a predominantly theoretical approach and Piketty draws the conclusion that inequalities cannot be overcome in capitalism, but be tamed and justified. Marx in contrast argues that capitalist antagonisms result again and again in crises that bring about human misery so that overcoming capitalism is the main political goal for the political left. 


\section{Capitalism and the Internet}

Thomas Piketty's (2014) references to the Internet and digital media are scarce. On the one hand this industry is of course just one among many and one should not overestimate its size. On the other hand, 15 IT and telecommunications companies are among the world's largest 100 companies (data source: Forbes 2000, 2014 list): Apple (\#15, operating systems, hardware, online sales), Samsung Electronics (\#22, semiconductors and hardware), AT\&T (\#23, telecommunications), Verizon (\#26, telecommunications), China Mobile (\#28, telecommunications), Microsoft (\#32, operating systems, application software), IBM (\#35, hardware, software, IT services), Vodafone (\#38, telecommunications), Google (\#52, Internet and mobile software), Nippon (\#61, telecommunications), Telefónica (\#68, telecommunications), Softbank (\#73, telecommunications), Intel (\#78, semiconductors), HP (\#80, hardware, software, IT services), Oracle (\#94, software, hardware, IT services). A 15\% share makes the IT and telecommunications sector quite relevant for the analysis of capitalism.

References to digital media are threefold in Piketty's book: He discusses the fetishism of Internet capitalism, changes brought about by technological progress, and the example of the new economy crisis in 2000.

First, Piketty discusses that there is a fetishism of the rich that disregards the social relations underlying this richness and the success and reputation of companies such as Microsoft, Apple, Facebook and Google. "Bill Gates, the former number one, who is seen as a model of the meritorious entrepreneur. At times one almost has the impression that Bill Gates himself invented computer science and the microprocessor. [...] No doubt the veritable cult of Bill Gates is an outgrowth of the apparently irrepressible need of modern democratic societies to make sense of inequality" (Piketty 2014, 444). "Steve Jobs, who even more than Bill Gates is the epitome of the admired and talented entrepreneur who fully deserves his fortune" (Piketty 2014, 440). Piketty stresses that monopolies and the exploitation of labour are crucial for the success of these companies: "it seems to me that Bill Gates also profited from a virtual monopoly on operating systems (as have many other high- tech entrepreneurs in industries ranging from telecommunications to Facebook, whose fortunes were also built on monopoly rents). Furthermore, I believe that Gates's contributions depended on the work of thousands of engineers and scientists doing basic research in electronics and computer science, without whom none of his innovations would have been possible" (Piketty 2014, 444).

Second, Piketty foregrounds that technological progress changes lifestyles, society and consumption as evidenced by the rise of the Internet and mobile phones. Annual growth of 1 percent would bring about major changes, as evidenced by the fact that in "1980 there was no Internet or cell phone network" (Piketty 2014, 95).

Third, Piketty discusses the 2000 new economy crisis as an example of bursting financial bubbles (Piketty 2014, 49, 172, 190, 295f). "To be sure, the price that the financial markets sets on a company's or even a sector's immaterial capital at any given moment is largely arbitrary and uncertain. We see this in the collapse of the Internet bubble in 2000, in the financial crisis that began in 2007-2008, and more generally in the enormous volatility of the stock market" (Piketty 2014, 49). "[T]he bursting of the Internet bubble in 2000- 2001, which caused a particularly sharp drop in the capital/income ratio in the United States and Britain" (Piketty 2014, 172).

The political economy of the Internet is complex and involves a manifoldness of dimensions and problems such as the exploitation of digital labour, the surveillance-industrial complex, struggles around intellectual property, an antagonism between knowledge commons and knowledge commodities, the role of the Internet in social struggles, the political economy of online attention, voice and visibility; complex relations between the public and the private; the creation, limitation and destruction of online public spheres; the rise of new forms of collaboration, etc (see: Fuchs 2008, 2011, 2014a, 2014b, 2014c; Fuchs, Boersma, Albrechtslund and Sandoval 2012; Fuchs and Mosco 2012, Fuchs and Sandoval 2014).

One of course does and should not expect from a general economist like Piketty to work out a political economy of the Internet. It rather makes sense to ask if there are elements in 
his approach that can help us in this task of better understanding the digital media economy in contemporary capitalism.

In the EU 28 countries, capital taxes accounted in 2014 for only $0.3 \%$ of the GDP (data source: AMECO). In the United States the value was $0.2 \%$ (ibid.). The projections for 2015 are $0.2 \%$ both for Europe and the USA (ibid.). This means that treated as a collective capitalist, companies hardly pay taxes. The lowering of capital taxation to almost nothing has since the 1970s come along, as Piketty (2014) shows in his book, with an increasing capital share and a decreasing wage share in most capitalist economies. If wages decrease while profits continue to increase, the exploitation of labour rises. Capital taxation is in principle a way of using state power for distributing wealth away from capital towards the general public by investing in public services that are available to all. The lowering of capital taxes helps further increasing profits and therefore increases the level of capitalism's inherent inequality between capital and labour. The "recent rise of tax competition in a world of free-flowing capital has led many governments to exempt capital income from the progressive income tax. This is particularly true in Europe, whose relatively small states have thus far proved incapable of achieving a coordinated tax policy. The result is an endless race to the bottom, leading, for example, to cuts in corporate tax rates and to the exemption of interest, dividends, and other financial revenues from the taxes to which labor incomes are subject (Piketty 2014, 496).

Transnational corporations tend to make use of financial outsourcing, tax havens and tax loopholes in order to avoid paying taxes. "The problem with the current system is that multinational corporations oft en end up paying ridiculously small amounts because they can assign all their profits artificially to a subsidiary located in a place where taxes are very low; such a practice is not illegal, and in the minds of many corporate managers it is not even unethical" (Piketty 2014, 561). Amazon has 15000 employees in the UK, but its headquarters are in Luxembourg, where it has just 500 employees $^{1}$. In 2011, it generated revenues of $£ 3.3$ billion in the UK, but only paid $£ 1.8$ million corporation tax $(0.05 \%)^{2}$. In 2013 , it paid $£ 4.2$ million in corporation tax $(0.1 \%)$ on sales of $£ 4.3$ billion $^{3}$. Facebook paid $£ 238000$ corporation tax on a UK revenue of $£ 175$ million $(0.1 \%)$ in $2011 .{ }^{4}$ Google had a UK turnover of $£ 395$ million in 2011, but only paid taxes of $£ 6$ million $(1.5 \%)^{5}$. The House of Commons' Public Accounts Committee under its Chair MP Margaret Hodge started an inquiry about corporate tax avoidance in 2012. Tax avoidance concerns not just Internet companies, but also other transnational corporations like Starbucks. The Internet is a global space. Companies selling commodities online (services, content, access to platforms, users) therefore operate automatically globally and are likely to have customers outside the country where their headquarters are located. It is therefore no surprise that among those companies that avoid paying taxes there are many Internet corporations. They outsource their finances in a complex manner to tax havens such as Luxembourg, the Bermuda Islands, the Cayman Islands or the Virgin Islands and argue that they don't have to pay taxes in those countries where their users or customers are located because the intellectual property for their platforms and/or their headquarters are registered in tax havens where they either have to pay no or only very low capital taxes.

In its inquiry, the Public Accounts Committee concluded: "Google defends its tax position by claiming that its sales of advertising space to UK clients take place in Ireland - an argument which we find deeply unconvincing on the basis of evidence that, despite sales being

\footnotetext{
${ }^{1}$ Starbucks, Google and Amazon grilled over tax avoidance. BBC Online. November 12, 2012. http://www.bbc.co.uk/news/business-20288077

${ }^{2}$ Amazon: £7bn sales, no UK corporation tax. The Guardian Online. April 4, 2012.

http://www.guardian.co.uk/technology/2012/apr/04/amazon-british-operation-corporation-tax. Google, Amazon,

Starbucks: The rise of "tax sharing". BBC Online. December 4, 2012.

http://www.bbc.co.uk/news/magazine-20560359

${ }^{3}$ Amazon boycott urged after retailer pays just $£ 4.2 \mathrm{~m}$ in tax. The Guardian Online. May 9, 2014.

http://www.theguardian.com/business/2014/may/09/margaret-hodge-urges-boycott-amazon-uk-tax-starbucks

${ }^{4}$ Should we boycott the tax-avoiding companies? The Guardian Online. Shortcuts Blog. October 17, 2012.

http://www.guardian.co.uk/business/shortcuts/2012/oct/17/boycotting-tax-avoiding-companies

${ }^{5}$ Starbucks, Google and Amazon grilled over tax avoidance. BBC Online. November 12, 2012.

http://www.bbc.co.uk/news/business-20288077
} 
billed from Ireland, most sales revenue is generated by staff in the UK. It is quite clear to us that sales to UK clients are the primary purpose, responsibility and result of its UK operation, and that the processing of sales through Google Ireland has no purpose other than to avoid UK corporation tax. [...] HMRC needs to be much more effective in challenging the artificial corporate structures created by multinationals with no other purpose than to avoid tax. [...] International tax rules are complicated and have not kept pace with the way businesses operate globally and through the internet. [...] it is far too easy for companies to exploit the rules and set up structures in low-tax jurisdictions, rather than pay tax where they actually conduct their business and sell their goods and services. We are also particularly concerned about the out-of-date tax frameworks covering international internet based commerce which rely on a fully automated process. [...] HMRC and HM Treasury should push for an international commitment to improve tax transparency, including by developing specific proposals to improve the quality and credibility of public information about companies tax affairs, and use that information to collect a fair share of tax from profits generated in each country. This data should include full information from companies based in tax havens" (House of Commons Committee of Public Accounts 2013, 5f).

Thomas Piketty $(2014,479)$ argues that the welfare state's funding of public services means that for services such as education and health there can be "real equality of access for everyone regardless of income (or parents' income), at least in principle". The welfare state certainly has the role of reproducing labour power so that it can be better exploited by capital. It however was also the outcome of long struggles of the working class and is therefore a working class achievement that has in the past decades been increasingly privatised, commodified and destroyed. Services of the welfare state that are available to all independent of income are an element of communism within capitalism. Modern society contains both elements of communism and capitalism that stand in a dialectical-contradictory relationship to each other. So communism is not something completely distant, but has its own realities and germ forms already today. The task of the political left is to question and struggle against the dismantling of communist elements and their replacement by elements of capitalism.

Piketty $(2014,494)$ argues that flat taxes such as consumption taxes "are often the most hated of all" because they put "the heaviest burden on the lower class". He suggests the introduction of a global progressive tax on capital and income for realising a $21^{\text {st }}$ century social state. The "capital tax I am proposing is a progressive annual tax on global wealth. The largest fortunes are to be taxed more heavily, and all types of assets are to be included: real estate, financial assets, and business assets - no exceptions" (Piketty 2014, 517). The problem is of course how to implement such a tax and to avoid capital flight. The problem is that taxation tends to be national, whereas capital is often global. It is however inappropriate to dismiss Piketty's suggestions as utopian and unrealistic (Harvey 2014, Žižek 2014). One should rather think about institutional reforms that need to be implemented along with a unified global progressive tax on capital.

The tax that Piketty $(2014,528,572)$ suggests is certainly too modest: $0 \%$ or $0.1 \%$ or $0.5 \%$ on wealth below 1 million Euros, $1 \%$ between $1-5$ million, $2 \%$ above 5 million. He also leaves open how high the global progressive tax on profits should be. If the same rates of $0 \%, 1 \%$ and $2 \%$ applied, then this would be a further tax relief for many companies and have no or negative redistributive effects that would further support capitalist interests. Corporate taxation should have much higher levels and could above a specific tax bracket be $100 \%$, i.e. a confiscatory tax, for that part of all annual profits that exceed a specific level. Piketty (2014, 505-508) himself shows that confiscatory taxes have historically played an important role especially in the USA and the UK.

"For collective action, what would matter most would be the publication of detailed accounts of private corporations (as well as government agencies)" (Piketty 2014, 570). Piketty here hints at the fact that Implementing a global progressive tax on capital requires not just institutions for a global tax system, but also a system that makes global financial flows and companies' revenues transparent to the public. This requires abolishing bank secrecy, or what some term financial privacy, of all companies in the world. Piketty (2014, 521-524). suggests a system that automatically transmits banking information to public tax authorities. 
Global computer networks are an indispensible tool for financial tracking and monitoring. One problem of taxing capital is indeed the intransparency of revenues and capital flows. One could therefore make an even more radical suggestion and suggest that all capital flows and corporate revenues should be transparent to everyone in the world. I imagine an open Internet system that allows everyone to track the annual revenues, profits and taxes of each company in the world broken down by geographic regions.

Alternative, non-commercial Internet and media platforms face the problem that dominant media and Internet corporations have often de-facto monopolies of audiences, users, attention, visibility and voices. The public sphere is in capitalism therefore necessarily undemocratic and unfree (Fuchs 2014d). I have suggested in another paper that it is crucial to provide and organise a resource base, visibility, voice and attention of alternative, noncommercial, non-profit Internet platforms and media in order to strengthen democracy in the digital and media age (Fuchs $2014 \mathrm{~d}$ ). The Internet is today highly controlled by capitalist corporations that exploit the digital labour of users and by state institutions that with the help of surveillance systems such as the Prism system whose existence Edward Snowden unveiled. The Internet is today highly controlled, unfree and undemocratic. An alternative Internet is urgently needed. Making the Internet non-capitalist would certainly require and constitute an Internet revolution. But the problem is how to start and how to support projects that are based on worker-user cooperatives, don't want to accumulate capital, but still need a resource base to exist.

Piketty argues for extending and modernising the social state in the $21^{\text {st }}$ century. He suggests that the public sector should involve "new decentralized and participatory forms of organization" (Piketty 2014, 482) and intermediary forms in which foundations and association co-operate with the state. The cultural and media sector would be a good realm for such forms (Piketty 2014, 483). I have suggested such reforms for the media and Internet sector (Fuchs 2014d): A politically progressive measure is to tax large media and other corporations based on a global corporation tax and to channel this income into non-commercial media, and to combine this measure with elements of participatory budgeting, which allows every citizens to receive and donate a certain amount per year to a non-commercial media project (Fuchs 2014d). Elements of state action and civil society action could be combined: the power of the state would guarantee taxation of large companies, the distribution of this income to media projects would however be decentralised and put in the hands of citizens.

Google, Facebook and other large online media companies hardly pay taxes in many countries. The insight that users are digital workers and create economic value on corporate social media that are financed by advertising allows changing global tax regulations: Corporate social media platforms should have to tax in a specific country that share of their revenues that corresponds to the share of users or ad-clicks/views in this country. Such a measure reflects Piketty's insight that it "makes more sense to give up the idea that profits can be pinned down to a particular state or territory; instead, one can apportion the revenues of the corporate tax on the basis of sales or wages paid within each country" (Piketty 2014, 561). Implementing such a tax system requires, as Piketty suggests, the global monitoring and transparency of company revenues and their financial flows, for which computer networks and the Internet are, as suggested above, excellent tools.

The licence fee - a tool of the broadcast age - could be developed into a media fee paid by citizens and companies. It could be made more socially just than the licence fee by implementing it not as a flat but a progressive fee that varies based on salary and revenue levels. It is a matter of fairness that those who earn more contribute more to the organisation of the common interest and public good.

The media fee could partly be used for directly funding public service media's online presence and partly be used in the form of participatory budgeting to provide an annual voucher to every citizen that s/he must donate to a non-profit, non-commercial media organisation. So participatory budgeting should not be used for deciding if the BBC receives the full costs it needs for its operations. Additional income from the media fee could however be distributed to alternative media projects with the help of participatory budgeting. Non-profit versions of Twitter, YouTube and Facebook run by civil society organisations and public institutions 
could based on such a model serve the purpose of the public sphere and strengthen the democratic character of communications.

The suggestion to tax capital is always likely to arouse among Marxists the reaction that such measures are just social-democratic reformism that does not abolish, but rather stablise capitalism. There is no doubt that Piketty (2014) does not want to abolish capitalism, but to establish "control of capitalism" (532), "to regulate capitalism" (518) and "to stop the indefinite increase of inequality of wealth" (518). This does however not mean that a global progressive tax on capital cannot be part of a radical-reformist political agenda of the left that tries to foster better conditions for the overcoming of capitalism. It is political idealism to think that the only thing we can do now is to build revolutionary movements and wait with the creation of democratic communism until the day after the revolution. We must start in the here and now with roots and seeds of democratic communism, i.e. participatory democracy. And such seeds need resources and have their own political economy. Channelling resources towards alternatives requires state power, state action, the interaction of progressive political parties and social movements, and interaction of the state and civil society. A global progressive tax on capital should be part of a strategy of a New Left to improve the living conditions of workers, consumers and users by weakening capitalism and capitalist interests. If implemented the right way together with other measures it can be a good tool of class struggle for a noncapitalist Internet.

Taxing Google, Facebook, Apple, Amazon etc more effectively, efficiently and transparently does certainly not abolish the exploitation of workers, prosumers and users. The important step is to establish non-capitalist digital media. Doing so requires resources. And these resources should be taken from large corporations. So effectively, efficiently and transparently taxing the likes of Google, Facebook or Apple is not a substitution for creating alternatives, but can become a means for fostering, creating, building and enlarging noncapitalist digital media and a way towards a non-capitalist Internet.

The second congress of the Communist League took place at the Red Lion pub in London from 29 November to 8 December 1847 (Briggs and Callow 2008, 35). As a result of it, "Marx and Engels were given the task of writing a Manifesto to publicise the doctrines of the League" (McLellan 2006, 161). One of ten concrete measures that the Commmunist Manifesto advocates is a "heavy progressive or graduated income tax" (Marx and Engels 1968, 51). A draft of the Manifesto titled Principles of Communism called for the "[l]imitation of private property through progressive taxation" (Engels 1847). A leaflet of the Communist Party in Germany that was written by Marx and Engels and signed by Marx, Engels, Karl Schapper, Heinrich Bauer, Joseph Moll and Wilhelm Wolff identified 17 demands, including the "[i]ntroduction of strongly progressive taxes and abolition of taxes on consumption" (Marx and Engels 1848a).

Engels already in 1845 suggested the introduction of public services financed by progressive taxes. In order to raise the money for public services and "at the same time replace all the present, unjustly distributed taxes, the present reform plan proposes a general, progressive tax on capital, at a rate increasing with the size of the capital. In this way, the burden of public administration would be shared by everyone according to his ability and would no longer fall mainly on the shoulders of those least able to bear it, as has hitherto been the case in all countries. For the principle of taxation is, after all, a purely communist one, since the right to levy taxes is derived in all countries from so-called national property" (Engels 1845).

The idea of progressive taxation remained important for Marx and Engels throughout their lives, as evidenced by the fact that Engels in 1891 commented on the draft of the German Social-Democratic Party's programme that progressive tax should "cover all expenditure of the state, district and community, insofar as taxes are required for it. Abolition of all indirect state and local taxes, duties, etc" (Engels 1891).

Marx and Engles did not reject parliamentary democracy, elections and state power, but saw them rather as a "means for putting through measures directed against private property and ensuring the livelihood of the proletariat" (Engels 1847). They recommended that "workers' candidates are nominated everywhere in opposition to bourgeois-democratic candidates" 
(Marx and Engels 1850). Elections and parliamentary democracy are for Marx and Engels (1850) part of the proletariat's "battle-cry [...]: The Permanent Revolution". They argued that the workers "must drive the proposals of the democrats to their logical extreme (the democrats will in any case act in a reformist and not a revolutionary manner) and transform these proposals into direct attacks on private property. If, for instance, the petty bourgeoisie propose the purchase of the railways and factories, the workers must demand that these railways and factories simply be confiscated by the state without compensation as the property of reactionaries. If the democrats propose a proportional tax, then the workers must demand a progressive tax; if the democrats themselves propose a moderate progressive tax, then the workers must insist on a tax whose rates rise so steeply that big capital is ruined by it; if the democrats demand the regulation of the state debt, then the workers must demand national bankruptcy. The demands of the workers will thus have to be adjusted according to the measures and concessions of the democrats" (Marx and Engels 1850).

Marx and Engels would today not reject, but embrace and radicalise the idea of a global progressive tax on capital. They saw progressive taxation as a communist measure. If we want to establish a non-capitalist Internet that benefits all humans as a commons, then fostering alternative Internet platforms and making use of elections, the state, governments, parliament, institutional reforms and progressive taxation for is a crucial measure.

Thomas Piketty's book "Capital in the Twenty-First Century" should neither be dignified nor denigrated. Neither should its importance be denied. Those interested in the creation of a New Left should constructively and critically engage with the book's ideas, which can help fostering a discourse about how left politics can look like today. The left has hardly benefitted and has not renewed itself since the capitalist crisis started in 2008. The far-right has in contrast in Europe had a large growth. A New Left is urgently needed. Books like Piketty's "Capital" are a welcome intervention. Activists, scholars, users and citizens struggling for an alternative Internet can gain insightful stimuli from it that can be further developed and radicalised. This is what Marx and Engels would have done. Radical reforms of the Internet are a crucial task today. A New Left is urgently needed. An alternative Internet is needed. The latter cannot be achieved without the first. And the first should take politics and struggles that help establishing the latter quite serious.

Rosa Luxemburg's words are in the age of the Internet more relevant than ever and should not be forgotten: "The daily struggle for reforms, for the amelioration of the condition of the workers within the framework of the existing social order, and for democratic institutions, offers to the social democracy the only means of engaging in the proletarian class war and working in the direction of the final goal-the conquest of political power and the suppression of wage labor. Between social reforms and revolution there exists for the social democracy an indissoluble tie. The struggle for reforms is its means; the social revolution, its aim" (Luxemburg 1899, 41).

\section{References}

Briggs, Asa and John Callow. 2008. Marx in London. London: Lawrence and Wishart.

Carchedi, Guglielmo and Michael Roberts. 2013. A critique of Heinrich's "Crisis theory, the law of the tendency of the profit rate to fall, and Marx's studies in the 1870s". Monthly Review Online: http://monthlyreview.org/commentary/critique-heinrichs-crisis-theory-law-tendency-profit-rate-fallmarxs-studies-1870s\#en1

Chotiner, Isaac. 2014. "Marx? I never really managed to read it" - an interview with Thomas Piketty. New Statesman Online May 6, 2014: http://www.newstatesman.com/politics/2014/05/marx-i-neverreally-managed-read-it-interview-thomas-piketty

Collins, Sean. 2014. Pricking the Piketty bubble. Spiked May 9, 2014: http://www.spikedonline.com/review_of_books/article/pricking-the-Piketty-bubble/14997\#.U4KWPy8UYWE

Despain, Hans G. 2014. Review of Thomas Piketty's "Capital in the twenty-first century". Marx \& Philosophy Review of Books: http://marxandphilosophy.org.uk/reviewofbooks/reviews/2014/1005

Douthat, Rose. 2014. Marx rises again. New York Times Online April 19, 2014 : http://www.nytimes.com/2014/04/20/opinion/sunday/douthat-marx-rises-again.html 
Ebermann, Thomas, Michael Heinrich, Robert Kurz and Joseph Vogl. 2011. No way out? Kapital kaputt? Krisengipfel-Gespräch. Konkret 12/2011: 12-16.

Engels, Friedrich. 1845. Speeches in Elberfeld. http://marxists.anu.edu.au/archive/marx/works/1845/02/15.htm

Engels, Friedrich. 1847. Principles of communism. http://marxists.org/archive/marx/works/1847/11/prin-com.htm

Engels, Friedrich. 1891. A critique of the draft Social-Democratic Programme of 1891. http://marxists.anu.edu.au/archive/marx/works/1891/06/29.htm

Erlanger, Steven. 2014. Taking on Adam Smith (and Karl Marx). New York Times Online April 19, 2014: http://www.nytimes.com/2014/04/20/business/international/taking-on-adam-smith-and-karlmarx.html

Fuchs, Christian. 2002. Krise und Kritik in der Informationsgesellschaft. Norderstedt: Libri.

Fuchs, Christian. 2004. The antagonistic self-organization of modern society. Studies in Political Economy 73: 183-209.

Fuchs, Christian. 2008. Internet and society: Social theory in the information age. New York: Routledge.

Fuchs, Christian. 2011. Foundations of critical media and information studies. London: Routledge.

Fuchs, Christian. 2014a. Digital labour and Karl Marx. New York: Routledge.

Fuchs, Christian. 2014b. OccupyMedia! The Occupy movement and social media in crisis capitalism. Winchester: Zero Books.

Fuchs, Christian. 2014c. Social media: A critical introduction. London: Sage.

Fuchs, Christian. 2014d. Social media and the public sphere. Inaugural lecture. tripleC: Communication, Capitalism \& Critique 12 (1): 57-101

Fuchs, Christian, Kees Boersma, Anders Albrechtslund and Marisol Sandoval, eds. 2012. Internet and surveillance. The challenges of web 2.0 and social media. New York: Routledge.

Fuchs, Christian and Vincent Mosco, eds. 2012. Marx is back. The importance of Marxist theory and research for critical communication studies today. tripleC: Communication, Capitalism \& Critique 10 (2): 127-632.

Fuchs, Christian and Marisol Sandoval, eds. 2014. Critique, social media and the information society. New York: Routledge.

Fuchs, Christian and Marisol Sandoval. 2014b. Introduction: Critique, social media and the information society in the age of capitalist crisis. In Critique, social media and the information society, ed. Christian Fuchs and Marisol Sandoval, 1-47. New York: Routledge.

Galbraith, James K. 2014. Kapital for the twenty-first century? Dissent Magazine Online Spring 2014: http://www.dissentmagazine.org/article/kapital-for-the-twenty-first-century

Giles, Chris and Ferdinando Giugliano. 2014. Flawed data on rich weaken Piketty's main argument. Financial Times May 24/25, 2014: 5.

Harvey, David. 2014. Afterthoughts on Piketty's Capital. http://davidharvey.org/2014/05/afterthoughtspikettys-capital/

Heinrich, Michael. 2013a. Crisis theory, the law of the tendency of the profit rate to fall, and Marx's studies in the 1870s. Monthly Review 64 (11): 15-31.

Heinrich, Michael. 2013b. Heinrich answers critics. Monthly Review Online: http://monthlyreview.org/commentary/heinrich-answers-critics

House of Commons Committee of Public Accounts. 2013. Tax avoidance - Google. Ninth report of session 2013-2014. London: The Stationery Office Limited.

Kliman, Andrew. 2012. The failure of capitalist production. Underlying causes of the great recession. New York: Pluto.

Kliman, Andrew. 2014. "The 99\%" and "the 1\%" ... of what? http://www.marxisthumanistinitiative.org/economic-crisis/\%E2\%80\%9Cthe-99\%E2\%80\%9D-and$\%$ E2\%80\%9Cthe-1\%E2\%80\%9D-\%E2\%80\%A6-of-what.html

Kliman, Andrew, Alan Freeman, Nick Potts, Alexes Gusey and Brendan Cooney. 2013. The unmaking of Marx's Capital: Heinrich's attempt to eliminate Marx's crisis theory. SSRN Working Papers Series (22. July 2013): http://mpra.ub.uni-muenchen.de/48535/1/MPRA_paper_48535.pdf

Krugman, Paul. 2014a. Is Piketty all wrong? The New York Times Online May 24, 2014: http://krugman.blogs.nytimes.com/2014/05/24/is-piketty-all-wrong/?_php=true\&_type=blogs\&_r=0

Krugman, Paul. 2014b. Why we're in a new gilded age. The New York Review of Books May 8, 2014: http://www.nybooks.com/articles/archives/2014/may/08/thomas-piketty-new-gilded-age/ 
Luxemburg, Rosa. 1899. Reform or revolution. In The essential Rosa Luxemburg, 41-104. Chicago, IL: Haymarket Books.

Mage, Shane. 2013. Response to Heinrich - In defense of Marx's law. Monthly Review Online: http://monthlyreview.org/commentary/response-heinrich-defense-marxs-law

Marx, Karl. 1857/58. Grundrisse. London: Penguin.

Marx, Karl. 1867. Capital. Volume 1. London: Penguin.

Marx, Karl. 1885. Capital. Volume 2. London: Penguin.

Marx, Karl. 1894. Capital. Volume 3. London: Penguin.

Marx, Karl and Friedrich Engels. 1848a. Demands of the Communist Party in Germany. http://marxists.org/archive/marx/works/1848/03/24.htm

Marx, Karl and Friedrich Engels. 1848b. Manifest der Kommunistischen Partei. In Marx Engels Werke (MEW), Band 3, 459-493. Berlin: Dietz.

Marx, Karl and Friedrich Engels. 1850. Addresses of the Central Committee to the Communist League. http://www.marxists.org/archive/marx/works/1847/communist-league/1850-ad1.htm

Marx, Karl and Friedrich Engels. 1968. Selected works in one volume. London: Lawrence \& Wishart.

Mason, Paul. 2014. Thomas Piketty's Capital: everything you need to know about the surprise bestseller. The Guardian Online April 28, 2014:

http://www.theguardian.com/books/2014/apr/28/thomas-piketty-capital-surprise-bestseller

McLellan, David. 2006. Karl Marx: A biography. Basingstoke: Palgrave Macmillan.

Moseley, Fred. 2013. Critique of Heinrich: Marx did not abandon the logical structure. Monthly Review Online: http://monthlyreview.org/commentary/critique-heinrich-marx-abandon-logical-structure

Mount, Ferdinand. 2014. Piketty's decaff Marxism would be just oppressive and intrusive as the old variety. The Spectator Online May 24, 2014: http://www.spectator.co.uk/books/9210671/capital-in-the-twenty-first-century-by-thomas-pikettyreview/

Pethoukis, James. 2014. The new Marxism. National Review Online March 24, 2014: http://www.nationalreview.com/article/374009/new-marxism-james-pethokoukis

Piketty, Thomas. 2014. Capital in the twenty-first century. Cambridge, MA: Belknap Press.

Rankin, Jennifer. 2014. Thomas Piketty accuses Financial Times of dishonest criticism. The Guardian Online May 26, 2014: http://www.theguardian.com/business/2014/may/26/thomas-piketty-financialtimes-dishonest-criticism-economics-book-inequality

Shenk, Timothy. 2014. Thomas Piketty and millennial Marxists on the scourge of inequality. The Nation Online April 14, 2014: http://www.thenation.com/article/179337/thomas-piketty-and-millennialmarxists-scourge-inequality

Shuchman, Daniel. Thomas Piketty revives Marx for the 21st century. The Wall Street Journal Online April 21, 2014: http://online.wsj.com/news/articles/SB10001424052702303825604579515452952131592

The Economist. 2014. Piketty fever. Bigger than Marx. The Economist Online May 3, 2014 : http://www.economist.com/news/finance-and-economics/21601567-wonky-book-inequalitybecomes-blockbuster-bigger-marx

The New York Times. 2014. Was Marx right? The New York Times Online March 30, 2014: http://www.nytimes.com/roomfordebate/2014/03/30/was-marx-right

Žižek, Slavoj. Towards a materialist theory of subjectivity. Talk at the Birkbeck Institute of Humanities. London. May 22, 2014. http://simongros.com/audio/recordings/slavoj-zizek/towards-materialisttheory-subjectivity/, http://simongros.com/text/articles/slavoj-zizek/comments-thomas-pikettys-lecapital-au-xxie-siecle/

\section{About the Author}

\section{Christian Fuchs}

is professor of social media at the University of Westminster's Communication and Media Research Institute and the Centre for Social Media Research. He is editor of tripleC: Communication, Capitalism \& Critique and author of many publications, including the books Social Media: A Critical Introduction (Sage 2014), Digital Labour and Karl Marx (Routledge 2014), OccupyMedia! The Occupy Movement and Social Media in Crisis Capitalism (Zero Books 2014), Foundations of Critical Media and Information Studies (Routledge 2011), Internet and Society: Social Theory in the Information Age (Routledge 2008). He recently edited together with Marisol Sandoval the collected volume Critique, Social Media and the Information Society (Routledge 2014). 